\title{
Pengaruh Return on Equity, Return on Asset, dan Firm Size Terhadap Tingkat Underpricing Saham Perusahaan yang Melakukan Go-Public di Bursa Efek Indonesia Periode 2016 - 2019
}

\author{
Muhamad Syahwildan \\ Universitas Pelita Bangsa \\ muhamad.syahwildan@pelitabangsa.ac.id \\ Muhamad Aminudin \\ Universitas Pelita Bangsa \\ aminudinmuhamad673@gmail.com
}

\begin{abstract}
The purpose of this study was to analyze the effect of financial and nonfinancial ratios in the form of return on equity, return on assets, and firm size on the level of underpricing. The hypothesis is tested using multiple linear regression analysis methods. The data used in this research are annual financial report data, opening stock price on the first trading day, and closing stock price on the first trading day. Eviews 10 is an analytical tool used in research. Sampling in this study used a purposive sampling method and obtained data from 75 companies from 160 companies that carried out the Go-public process on the Indonesian Stock Exchange for the period 2016-2019. The analytical method used is quantitative methods. The results of this study indicate that the return on equity (ROE) and return on assets (ROA) variables do not have a significant effect on the level of underpricing of the shares of companies that go public on the Indonesian Stock Exchange in the 2016-2019 period, while the firm size variable has a significant effect. on the level of underpricing of shares of companies that went public on the Indonesian stock exchange for the 2016-2019 period
\end{abstract}

Keywords : : Return on equity, Return on asset, Firm Size and Underpricing

\section{PENDAHULUAN}

Era Globalisasi saat ini, persaingan dalam dunia bisnis di Indonesia semakin meningkat. Banyak perusahaan yang membutuhkan dana besar untuk pengembangan usahanya. Berbagai perusahaan giat melakukan ekspansi dengan memperluas usahanya untuk memasuki ruang lingkup global, tujuannya agar tetap bertahan dalam dunia bisnis yang semakin meningkat. Salah satu alternatif perusahaan dalam penambahan modal untuk kegiatan pengembangannya yaitu dengan menambah jumlah kepemilikan saham baru dengan cara melakukan go-public dan mencatatkan sahamnya dibursa efek indonesia (Akbar \& Africano, 2020). Dalam kurun waktu 4 tahun terakhir 160 perusahaan dari berbagai sektoral telah melakukan go-pubik dibursa efek indonesia (www.idx.co.id). Perusahaan pada Bursa efek Indonesia akan mendapatkan modal tambahan dengan cara menambah jumlah kepemilikan saham baru dan menjual saham tersebut kepada masyarakat dan hal ini akan meningkatkan pertumbuhan dan perkembangan perusahaan seiring dengan memenuhi kebutuhan pasar. 
Modal yang didapatkan perusahaan bersumber dari internal dan eksternal, modal internal didapatkan dari laba hasil penjualan,sedangkan dari eksternal modal didapatkan dengan cara perusahaan mempublikasikan saham baru, menjual obilgasi dan mendapat pinjaman dari Bank (Mayasari et al., 2018) . Dengan pendanaan yang besar, perusahaan akan terus berinovasi menjadikan produk yang diperlukan di masyarakat dapat terpenuhi. Beberapa alasan perusahaan melakukan go-public diantaranya untuk memperluas usahanya, tidak menambah hutang baru dan kemudian mengganti hutang sebelumnya dengan keuntungan yang didapatkan dari penawaran perdana dipasar saham (Hadi, 2019). Harga saham yang diperjual-belikan sebelumnya telah ditetapkan dengan kesepakatan dari emiten dengan penjamin emisi.

Penambahan modal dari pasar saham itu sendiri tidak selamanya terpenuhi. Ada dua kondisi yang sering terjadi di indonesia dan luar negri dalam pasar saham saat terjadi Initial public offering yaitu kondisi Overpricing dan Underpricing (D. Alviani \& Lasmana, 2015) . Overpricing itu sendiri dimana kondisi harga saham dipasar primer lebih tinggi dibandingakan dengan harga dipasar Secondary. Sedangkan kondisi Underpricing disebabkan oleh penawaran saham dipasar primer lebih rendah dibandingkan penawaran saham dipasar Secondary.

Situasi Underpricing sering terjadi ketika suatu perusahaan melakukan penanaman modalnya dibursa efek dimana saham yang ditawarkan dipasar sekunder lebih tinggi dibandingan ketika di pasar primer dan harga saham tersebut telah ditentukan oleh kedua belah pihak yakni penerbit dan penjamin emisi (Yuliani et al., 2019). Menurut Haska et al., (2016) perusahaan dan investor menerima dampak yang ditimbukan dari kondisi underpricing diantaranya perusahaan tidak mendapatkan dana yang maksimal, sedangkan jika terjadi kondisi overpricing, investor dirugikan yang disebabkan adanya perbedaan nilai dipasar perdana saat terjadinya proses initial public offering dengan nilai jual yang berlangsung dipasar sekunder. Sehingga investor harus mengerti rasio keuangan sebagai indikator untuk mengetahui apakah sebuah perusahaan dapat menghasilkan keuntungan bagi investor.

Dalam penelitian yang dilakukan sebelumnya menggunakan rasio keuangan dan non keuangan yang menjadi variabel penelitian seperti return on equity (ROE), return on asset (ROA) dan Ukuran perusahaan (Firm size) yang berpengaruh terhadap tingkat underpricing saham yang melakukan go-public dibursa efek indonesia. Variabel return on equity (ROE) ini pernah diteliti oleh Mayasari et al., (2018) mendapat kesimpulan bahwa variabel return on equity (ROE) dan Ukuran Perusahaan (Firm size) berpengaruh signifikan terhadap tingkat underpricing.

Variabel return on equity (ROE) berpengaruh signifikan terhadap terjadinya underpricing (Dewi et al., 2018). Selanjutnya penelitian oleh F. A. Lestari \& Sulasmiyati, (2017) dalam variabel yang digunakannya mendapat kesimpulan bahwa return on equity (ROE) dan return on asset (ROA) berpengaruh signifikan terhadap tingkat underpricing. Penelitian dilakukan oleh (Widhiastina \& Prihatni, 2016) mendapat hasil bahwa variabel return on asset (ROA) memiliki pengaruh signifikan terhadap tingkat underpricing. Penelitian selanjutnya yang dilakukan oleh. (Wiyani, 2016) mendapat kesimpulan dalam variabel Return on equity (ROE) dan Ukuran Perusahaan (Firm size) yang berpengaruh secara signifikan terhadap Underpricing.

Sementara hasil yang berlawanan ditemukan dalam penelitian Djasan (Djasan, 2018) menghasikan variabel return on asset (ROA) dan ukuran perusahaan (Firm size) tidak adanya pengaruh signifikan terjadinya proses underpricing. Hal serupa juga dapat ditemui dalam penelitian yang dilakukan (Muharam \& Firmanah, 2015) dimana variabel 
return on asset (ROA) dan Ukuran perusahaan (firm size) tidak terdapat pengaruh secara signifikan terhadap tingkat Underpricing. Hasil yang berlawanan juga pada (Valantina et al., 2017) menyimpulakn variabel dari return on asset (ROA) tidak memiliki pengaruh terhadap terjadinya Underpricing. Penelitian ini bertujuan untuk menganalisis pengaruh variabel return on equity (ROE), return on asset (ROA), dan ukuran perusahaan (firm size).

\section{LANDASAN TEORI \\ Underpricing}

underpricing merupakan kerjadian dimana nilai harga jual saham pada penawaran pertama dipasar perdana lebih murah dibandingakan dengan nilai harga jual saham saat diperdagangkan dipasar sekunder (Mayasari et al., 2018). Sehingga dapat diasumsikan bahwa selisih harga penawaran perdana cenderung lebih rendah dibandingkan harga saham saat penutupan dihari pertama pasar sekunder. Kondisi Underpricing terjadi karena adanya perbedaan positif antara harga saham pada saat dipasar sekunder dengan harga saham yang ditawarkan di pasar perdana atau penawaran saham perdana saat initial public offering (IPO) (Setyowati \& Suciningtyas, 2018). ketidakseimbangan informasi yang didapat dari kedua belah pihak antara pihak perusahaan dan pihak underwriter yang menyebabkan perbedaan harga dipasar perdana sehingga terjadilah underpricing (Saifudin \& Rahmawati, 2017)

\section{Return On Equity (ROE)}

Return on equity (ROE) merupakan Besarnya perolehan modal yang diinvestasikan untuk mendapatkan keuntungan kepada investor, caranya dengan membandingkan Laba bersih perushaaan dengan Ekuitas (Mayasari et al., 2018). Return on equity (ROE) adalah Ukuran efektivitas perusahaan dalam mengelola modal yang ada sehingga menghasilkan laba (Yuliani et al., 2019). Bagi investor, Return on equity (ROE) menjadi salah satu faktor yang harus diperhatikan sebelum membeli saham perusahaan. Return on equity (ROE) merupakan Nilai yang memperlihatkan bahwa perusahaan dapat memperoleh keuntungan dimasa depan, dan keuntungan tersebut menjadi sebuah informasi berharga bagi para investor untuk mempertimbangkan dalam penanaman modalnya (Dewi et al., 2018)

\section{Return On Asset (ROA)}

Return On Asset (ROA) adalah Rasio Profitabilitas yang memanfaatkan perusahaan dalam menciptakan keuntungan dengan cara menggunakan asset yang dimilikinya, dan jika perolehan Return On Asset (ROA) suatu perusahaan tinggi maka akan memperlihatkan bahwa kinerja perusahaan dalam memperoleh keuntungan yang tinggi dimasa mendatang (Nadia \& Daud, 2017). Return on asset (ROA) adalah Rasio yang sering dipergunakan untuk mengukur kinerja dan kemampuan sebuah perusahaan dalam menghasilkan keuntungan dari total aktivanya, Return on asset (ROA) itu sendiri menjadi alasan para investor untuk berinvestasi diperusahaan tersebut (Saputra \& Suaryana, 2016). Rasio untuk mengukur tingkat profitabilitas dilakukan dengan berbagai cara, salah satu rasio yang dipergunakan untuk profitabilitas itu sendiri yaitu Return on asset (ROA) dimana Laba bersih atas Aset, rasio ini mengukur kemampuan perusahaan untuk mendapatkan keuntungan dari penggunaan asetnya (Utami et al., 2019) 


\section{Ukuran Perusahaan (Firm Size)}

Pada umumnya perusahaan yang memiliki ukuran atau skala yang besar mudah dikenali oleh masyarakat dibandingkan dengan ukuran atau skalanya yang kecil (Gunawan \& Jodin, 2017). Ukuran perusahaan dapat didefinisikan sebagai suatu parameter besar atau kecilnya benda atau obyek dalam hal ini perusahaan. Besar kecilnya ukuran perusahaan diperlihatkan dari asset (kekayaan) yang dimilikinya (Widhiastina \& Prihatni, 2016). Ukuran perusahaan merupakan kapasitas yang dapat diukur dengan besarnya aset yang dimilinya, besarnya perusahaan tersebut biasanya memiliki aset dan nilai yang tinggi (Wiyani, 2016). Ukuran perusahaan dalam hal ini merupakan gambaran dari skala perusahaan yang muncul dari jumlah total aset dari perusahaan, semakin besar ukuran perusahaan maka semakin banyak minat investor untuk berinvestasi diperusahaan tersebut (Rabiqy, 2017)

\section{Pengembangan Hipotesis Penelitian}

$\mathrm{H}_{1}$ : Return on equity (ROE) berpengaruh terhadap tingkat underpricing.

Return On Equity (ROE) adalah Rasio perbandingaan antara laba bersih setelah pajak dengan total ekuitas, oleh karena itu return on equity menjadi tolak ukur untuk melihat kemampuan perusahaan dalam menghasilkan laba. Dalam return on equity itu sendiri berisi informasi yang dapat diberikan kepada investor tentang seberapa besar pengembalian modal yang telah ditanamkan dalam menghasilkan keuntungan bagi investor. Variabel return on equity (ROE) berpengaruh terhadap tingkat underpricing (Hadi, 2019). Sementara hasil berbeda ditemui dalam penelitian lain yang menjelaskan tentang penelitiannya bahwa variabel return on equity (ROE) tidak berpengaruh signifikan terhadap tingkat underpricing (Saifudin \& Rahmawati, 2017).

\section{$\mathrm{H}_{2}$ : Return on asset (ROA) berpengaruh terhadap tingkat underpricing.}

Return on asset (ROA) merupakan rasio profitabilias yang mengukur kemampuan perusahaan untuk menghasilkan laba atau keuntungan dari asset yang dimilikinya. Dalam perbandingan laba bersih yang didapatkan atas total asset yang dimiliki perusahaan. Return on asset juga menjadi salah satu rasio yang digunakan dalam penelitian ini karena untuk mengukur efektivitas perusahaan dalam menghasilkan keuntungan. Dalam hal ini ukuran perusahaan menjadi tolak ukur yang penting bagi para investor untuk menanamkan modalnya. Penelitian sebelumnya menyimpulkan bahwa variabel return on asset (ROA) berpengaruh signifikan terhadap underpricing, karena hasil yang ditunjukan telah terbukti bahwa return on asset (ROA) berpengaruh signifikan terhadap tingkat underpricing (Widhiastina \& Prihatni, 2016)

\section{$\mathrm{H}_{3}$ : Ukuran perusahaan (firm size) berpengaruh terhadap tingkat underpricing.}

Ukuran perusahaan menggambarkan besar kecilnya suatu perusahaan. Dalam kontek masyarakat sebuah perusahaan dengan skala yang besar dapat dikenali dengan mudah dibandingkan dengan perusahaan dengan skala yang kecil. Sehingga investor lebih mudah mendapat informasi yang dapat dan digunakan untuk investasi karena cenderung investor lebih suka berinvestasi diperusahaan yang skalanya besar. Perusahaan dengan skala besar tidak dapat dipengaruhi oleh pasar, justru sebaliknya perusahaan tersebut dapat mempengaruhi pasar secara keseluruhan. Penelitian sebelumnya menjelaskan bahwa bahwa ukuran perusahaan berpengaruh terhadap tingkat underpricing (Permatasari \& Kusumah, 2017) 


\section{METODE PENELITIAN}

Jenis Penelitian ini menggunakan metode kuantitatif yang bertujuan untuk menguji hipotesis dengan menganalisa adanya pengaruh dari Return on Equity (X1), variabel X2 yaitu Return on asset (X2), dan Ukuran Perusahaan (X3) terhadap underpricing ( $Y$ ) saham perusahaan yang melakukan go-public dibursa efek indonesia periode tahun 2016-2019 . Penelitian ini dilakukan selama 4 bulan dari bulan januari hingga April 2020. Populasi yang digunakan dalam penelitian ini adalah Perusahaan yang melakukan Intital Publik Offering (IPO) dan mencatat sahamnya di Bursa Efek Indonesia dalam Periode 20162019. Sampel penelitian yang diambil dari perusahaan yang melakukan IPO dari tahun 2016-2019. Secara total, terdapat 160 perusahaan yang melakukan IPO pada kurun waktu tersebut. Sampel yang digunakan adalah perusahaan yang mengalami kondisi underpricing dan memiliki laporan keuangan yang lengkap serta menggunakan mata uang rupiah dengan jumlah 75 perusahaan. Pengambilan sampel menggunakan teknik purposive sampling, dengan pertimbangan khusus dan memiliki kriteria tertentu. Jenis data yang digunakan dalam penelitian ini adalah data sekunder yang didapatkan secara tidak langsung melalui media perantara yaitu www.idx.co.id. Metode Analisis yang digunakan adalah regresi linier berganda dengan software eviews sebagai alat analisis.

\section{HASIL PENELITIAN}

\section{Uji T Statistik (Uji t )}

Secara parsial atau individual, uji-t menunjukan seberapa jauh pengaruh variabel independen dalam menerangkan variabel dependen. Uji ini bertujuan untuk mengetahui pengaruh tersebut signifikan atau tidak antara variabel independen terhadap variabel dependen. Penyajian dalam hipotesis ini menggunakan tingkat signifikansi 5\% $(\alpha=0,05)$.

Tabel 1. Uji t- Parsial

\begin{tabular}{crrrr}
\hline \hline \multicolumn{1}{c}{ Variable } & Koefisien & Std. Error & t-Statistic & Prob. \\
\hline \hline C & 61.85921 & 3.852867 & 16.05537 & 0.0000 \\
ROE & -0.621902 & 0.393682 & -1.579706 & 0.1186 \\
ROA & -0.112304 & 0.401296 & -0.279854 & 0.7804 \\
\multicolumn{1}{c}{ UKURAN } & $-5.35 \mathrm{E}-12$ & $2.12 \mathrm{E}-12$ & -2.524985 & 0.0138 \\
\hline \hline & & & & \\
R-squared & 0.168562 & Mean dependent var & 50.73000 \\
Adjusted R-squared & 0.133431 & S.D. dependent var & 22.57424 \\
S.E. of regression & 21.01429 & Akaike info criterion & 8.980141 \\
Sum squared resid & 31353.63 & Schwarz criterion & 9.103740 \\
Log likelihood & -332.7553 & Hannan-Quinn criter. & 9.029493 \\
F-statistic & 4.798081 & Durbin-Watson stat & 1.997242 \\
Prob(F-statistic) & 0.004230 & & & \\
\hline \hline
\end{tabular}

Sumber : Data diolah,2020

Uji t ini digunakan untuk mengetahui variabel independen Return On Equity (ROE), Return On Asset (ROA) dan Ukuran Perusahaan (Firm Size) memiliki pengaruh secara 
parsial terhadap variabel dependen yaitu underpricing. Berikut analisis masing-masing variabel independen terhadap variabel dependen :

a. Return On Equity (ROE) terhadap Underpricing

Nilai t-statistik pada varaibel Return On Equity (ROE) sebesar -1.579706 yang berarti nilai t-statistik (1.579706) lebih kecil dari nilai t-tabel (1.99346), atau t-statistik ($1.579706)<\mathrm{t}$-tabel (1.99346). Selain itu nilai probabilitas ROE yang didapatkan 0.1186 lebih besar dari nilai signifikansi 0.05 , atau nilai probabilitas $0.1186>0.05$, Maka H0 diterima dan Ha ditolak, jadi ROE secara parsial tidak memiliki pengaruh signifikan kearah negatif terhadap tingkat underpricing .

b. Return On Asset (ROA) terhadap Underpricing

Nilai t-statistik pada variabel Return On Asset (ROA) sebesar -0.279854 yang berarti nilai t-statistik (-0.279854) lebih kecil dari nilai t-tabel (1.99346), atau t-statistik ($0.279854)<$ nilai t-tabel (1.99346). Selain itu nilai probabilitas ROA yang didapatkan sebesar 0.7804 lebih besar dari nilai signifikansi 0,05 , atau nilai probabilitas ROA 0.7804 $>$ 0,05. Maka H0 diterima dan Ha ditolak. Jadi Variabel ROA secara parsial tidak memiliki pengaruh signifikan kearah negatif terhadap tingkat underpricing.

c. Ukuran Perusahaan (Firm Size) Terhadap Underpricing

Nilai t-statistik pada variabel Ukuran Perusahaan (Firm Size) sebesar -2.524985 yang berarti nilai t-statistik (-2.524985) lebih besar dari nilai t-tabel (1.99346), atau t-statistik $(-2.524985)>\mathrm{t}$-tabel (1.99346). Selain itu nilai probabilitas Ukuran perusahaan (Firm size) yang didapatkan sebesar 0.0138 lebih kecil dari nilai signifikansi 0,05 atau nilai probabilitas Ukuran perusahaan $0.0138<0,05$. Maka H0 ditolak dan Ha diterima. Jadi variabel Ukuran Perusahaan (firm size) secara parsial memiliki pengaruh signifikan kearah negatif terhadap tingkat underpricing.

\section{Koefisien Determinasi ( Adjusted $\boldsymbol{R}^{2}$ )}

Koefisien determinasi (Adjusted $\mathrm{R}^{2}$ ) untuk menjelaskan seberapa besar pengaruh variabel dependen yaitu underpricing dapat dijelaskan oleh variabel independen yaitu Return On Equity (ROE), Return On Asset (ROA) dan Ukuran Perusahaan (Firm Size). Berikut hasil dari pengujian koefisien determinasi pada tabel 2 dibawah ini :

Tabel 2. Koefisien Determinasi

\begin{tabular}{lrll}
\hline \hline R-squared & 0.168562 & Mean dependent var & 50.73000 \\
Adjusted R-squared & 0.133431 & S.D. dependent var & 22.57424 \\
S.E. of regression & 21.01429 & Akaike info criterion & 8.980141 \\
Sum squared resid & 31353.63 & Schwarz criterion & 9.103740 \\
Log likelihood & -332.7553 & Hannan-Quinn criter. & 9.029493 \\
F-statistic & 4.798081 & Durbin-Watson stat & 1.997242 \\
Prob(F-statistic) & 0.004230 & & \\
\hline \hline
\end{tabular}

Sumber : Data diolah,2020 
Berdasarkan nilai dari Adjusted R-squared sebesar 0.133431 yang artinya besarnya pengaruh dari variabel return on equity (ROE), return on asset (ROA) dan ukuran perusahaan (firm size) terhadap tingkat underpricing sebesar $13.3431 \%$, sementara untuk sisanya sebesar 86.6569 dipengaruhi oleh variabel lain yang tidak dimasukan dalam penelitian ini.

Analisis regresi linear berganda digunakan untuk menguji apakah ada pengaruh dari variabel Return on equity (ROE), Return on asset (ROA) dan Ukuran perusahaan (Firm size), terhadap tingkat underpricing. Dengan menggunakan nilai signifikansi sebesar $\alpha=$ 0,05 .

Tabel 3. Hasil Uji Regresi Linier Berganda

\begin{tabular}{ccccc}
\hline \hline Variable & Koefisien & Std. Error & t-Statistic & Prob. \\
\hline \hline C & 61.85921 & 3.852867 & 16.05537 & 0.0000 \\
ROE & -0.621902 & 0.393682 & -1.579706 & 0.1186 \\
ROA & -0.112304 & 0.401296 & -0.279854 & 0.7804 \\
UKURAN & $-5.35 \mathrm{E}-12$ & $2.12 \mathrm{E}-12$ & -2.524985 & 0.0138 \\
\hline \hline
\end{tabular}

Sumber : Data diolah,2020

Berdasarkan tabel diatas maka dapat diperoleh persamaan regresi linear berganda sebagai berikut:

$\mathrm{UP}=61.85921+(-0.621902) \mathrm{ROE}+(-0.112304) \mathrm{ROA}+(-5.35 \mathrm{E}-12) \mathrm{UKURAN} .+\mathrm{E}$

Keterangan :

$\mathrm{UP}=$ Underpricing

$\mathrm{ROE}=$ Return on equity

$\mathrm{ROA}=$ Return on asset

UKURAN $=$ Ukuran perusahaan (Firm size $)$

a. Nilai koefisien sebesar 61.85921, menunjukan tingkat underpricing sebesar 61.85921. artinya apabila nilai variabel dari return on equity (ROA), return on asset (ROA) dan Ukuran perusahaan (firm size) sama dengan nol akan menaikan tingkat underpricing sebesar 61.85921 dengan asumsi variabel lain tetap.

b. Nilai koefisien return on equity (ROE) sebesar -0.621902 menghasilkan bahwa apabila setiap kenaikan variabel return on equity (ROE) sebesar $1 \%$ maka akan menurunkan tingkat underpricing yang terjadi sebesar -0.621902 dengan asumsi variabel lain tetap.

c. Nilai koefisien return on asset (ROA) sebesar -0.112304 menghasilkan bahwa apabila setiap kenaikan variabel return on asset (ROA) sebesar $1 \%$ maka akan menurunkan tingkat underpricing yang terjadi sebesar -0.112304 dengan asumsi variabel lain tetap.

d. Nilai koefisien ukuran perusahaan (firm size) sebesar -5.35E-12 menghasilkan bahwa apabila setiap kenaikan variabel ukuran perusahaan (firm size) sebesar $1 \%$ maka akan menurunkan tingkat underpricing sebesar -5.35E-12 dengan asumsi variabel lain tetap.

Berdasarkan tabel 3. dengan menggunakan nilai signifikansi sebesar $\alpha=0,05$. Dapat disimpulkan nilai probabilitas ROE sebesar $0.1186 \geq 0.05$ maka variabel $\mathrm{ROE}$ tidak 
berpengaruh signifikan terhadap tingkat underpricing. Sementara variabel ROA sebesar $0.7804 \geq 0.05$, maka variabel ROA tidak berpengaruh terhadap tingkat underpricing. dan variabel ukuran perusahaan (Firm size) dengan nilai probabilitas sebesar $0.0138 \leq 0.05$ maka variabel ukuran perusahaan (Firm Size) memiliki pengaruh signifikan terhadap tingkat underpricing.

\section{Pengaruh return on equity (ROE) terhadap tingkat underpricing}

Berdasarkan pengujian yang telah dilakukan, variabel return on equity (ROE) tidak berpengaruh signifikan terhadap tingkat underpricing. Hasil ini bertentangan dengan hipotesis teori dan penelitian sebelumnya, maka hipotesis $\mathrm{H}_{1}$ ditolak. Artinya return on equity (ROE) tidak berpengaruh signifikan terhadap tingkap underpricing pada perusahaan yang melakukan go-public dibursa efek indonesia. Maka H0 diterima dan Ha ditolak, jadi ROE secara parsial tidak memiliki pengaruh signifikan kearah negatif terhadap tingkat underpricing. Karena ROE itu sendiri merupakan rasio keuangan yang menghitung laba bersih setelah pajak terhadap ekuitas, jadi apabila nilai ROE semakin kecil yang diperoleh oleh suatu perusahaan maka perusahaan tersebut sedang mengalami kesulitan atau dalam kondisi penurunan, begitu juga sebaliknya. Dalam hal ini investor tidak melihat dari segi ROE yang didapat oleh perusahaan, karena tidak selamanya perusahaan mengalami keuntungan pasti ada titik dimana perusahaan itu sedang mengalami kesulitan. Hasil ini juga didukung oleh penelitian Purwanto (2015) dan Asrini (2017) yang menghasilkan bahwa variabel retrun on equity (ROE) tidak berpengaruh signifikan terhadap tingkat underpricing. Saifudin (2017)menjelaskan tentang penelitiannya bahwa variabel return on equity (ROE) tidak berpengaruh signifikan terhadap tingkat underpricing karena jika tujuan investor untuk berinvestasi untuk jangka pendek, maka untuk investor jangak pendek ROE tidaklah penting karena saham yang mereka beli tidak akan ditahan dalam waktu yang lama. Hasil ini juga didukung oleh Harahap (2017) bahwa Variabel ROE tidak berpengaruh terhadap tingkat underpricing menunjukan adanya informasi asimetris dalam bentuk "informasi tersembunyi" yang menjadikan bahwa kurangnya penyampaian informasi public kepada investor, dalam hal ini investor cenderung berinvestasi dipasar primer hanya menggunakan laporan kinerja keuangan yang tercantum dalam profil resmi perusahaan, dan kemungkinan telah terjadinya manajemen laba sebelum IPO dapat membuatkan hasil terjadinya underpricing dalam jangka pendek dan kinerja buruk untuk jangka panjang setelah IPO. Namun hasil ini berlawanan dengan penelitian Dewi (2018) dan Lestari (2017) yang menyatakan variabel return on equity (ROE) berpengaruh signifikan terhadap tingkat underpricing.

\section{Pengaruh Return On Asset (ROA) Terhadap Tingkat Underpricing}

Dari hasil pengujian yang telah dilakukan bahwa variabel return on asset (ROA) tidak berpengaruh signifikan terhadap tingkat underpricing. Maka hipotesis $\mathrm{H}_{2}$ ditolak, karena bertentangan dengan hipotesis teori dan penelitian yang dilakukan sebelumnya. Jadi Variabel ROA secara parsial tidak memiliki pengaruh signifkan ke arah negatif terhadap tingkat underpricing. Berdasarkan hasil tersebut para investor melihat dan menghitung dengan rasio yang lain untuk menganalisis apakah perusahaan tersebut layak untuk diinvestasi, bukan hanya menggunakan ROA saja melainkan Rasio profitabilitas lainnya yang jauh lebih penting untuk melihat kinerja suatu perusahaan seperti NPM (Net Profit Margin, EPS (Earning Per Share), dan yang lainnya. Hasil penelitian ini mendukung dengan penelitian yang dilakukan oleh Purwanto (2015) bahwa variabel ROA tidak berpengaruh terhadap tingkat underpricing karena para investor tidak hanya melihat ROA 
dalam prospektus saja melainkan, investor juga beranggapan bahwa perusahaan telah melakukan manajemen laba, sehingga menganggap bahwa ROA dalam prospektus (profil perusahaan dan laporan tahunan resmi ) tidak menunjukan profitabiliats perusahaan yang sebenarnya. Sementara menurut hasil penelitian Adriansyah (2016) bahwa variabel return on asset (ROA) tidak berpengaruh signifikan terhadap tingkat underpricing, namun hasil ini berbanding terbalik dengan penelitian yang dilakukan oleh Setyowati (2018) yang menyatakan bahwa variabel profitabilitas yakni ROA berpengaruh signifikan terhadap tingkat underpricing.

\section{Pengaruh Ukuran perusahaan (firm size) Terhadap Tingkat Underpricing}

Hasil pengujian yang telah dilakukan menyatakan bahwa variabel ukuran perusahaan berpengaruh signifikan terhadap tingkat underpricing. Sementara variabel Ukuran Perusahaan (firm size) secara parsial memiliki pengaruh signifikan kearah negatif terhadap tingkat underpricing. Oleh karena itu para investor menilai bahwa semakin besar ukuran suatu perusahaan maka semakin besar juga keuntungan yang akan mereka terima, dengan melihat total aset yang dimilikinya para investor menilai perusahaan tersebut akan berkembang lebih baik buat kedepannya, serta perusahaan besar umunya lebih dikenal oleh masyarakat. Penelitian ini juga menemukan hasil yang sama dengan penelitian yang dilakukan oleh Wiyani (2016) dan Akbar (2020) bahwa ukuran perusahaan berpengaruh signifikan terhadap underpricing, Semakin besar ukuran sebuah perusahaan, maka tingkat resiko yang diterima semakin kecil sehingga tingkat terjadinya underpricing akan semakin rendah. Penelitian ini juga sejalan dengan Lestari (2017) bahwa Perusahaan bersekala besar cenderung tidak dipengaruhi oleh kondisi pasar tetapi lebih mempengaruhi kondisi pasar. Oleh karena itu, hal-hal yang mengurangi ketidakpastian investor untuk melakukan investasi pada perusahaan sehingga underpricing dapat dihindari. hasil yang sama juga terjadi penelitian yang dilakukan oleh Permatasari (2017) bahwa ukuran perusahaan berpengaruh terhadap tingkat underpricing. Hasil penelitian ini tidak mendukung dengan penelitian yang dilakukan oleh Purwanto (2015) bahwa variabel ukuran perusahaan tidak berpengaruh terhadap tingkat underpricing saham perusahaan yang melakukan initial public offering (IPO) dibursa efek indonesia.

\section{KESIMPULAN}

Berdasarkan variabel ROE, ROA dan Firm Size dengan jumlah sampel 75 perusahaan dari berbagai sektor dan terdaftar dibursa Indonesia periode 2016-2019 mendapatkan hasil bahwa variabel return on equity (ROE) tidak berpengaruh signifikan terhadap tingkat underpricing saham perusahaan yang melakukan go-public dibursa efek Indonesai periode 2016-2019 dan variabel ROE secara parsial tidak memiliki pengaruh signifikan kearah negatif terhadap tingkat underpricing. Variabel return on asset (ROA) tidak berpengaruh signifikan terhadap tingkat underpricing saham perusahaan yang melakukan go-public dibursa efek Indonesia periode 2016-2019 dan variabel ROA secara parsial tidak memiliki pengaruh signifikan kearah negatif terhadap tingkat underpricing. Sementara hasil dari variabel ukuran perusahaan (firm size) berpengaruh signifikan terhadap tingkat underpricing saham perusahaan yang melakukan go-public dibursa efek indonesia periode 2016 - 2019 dan variabel ukuran perusahaan secara parsial memiliki pengaruh signifikan kearah negatif terhadap tingkat underpricing saham perusahaan yang melakukan go-public di BEI periode 2016-2019 


\section{DAFTAR PUSTAKA}

Adriansyah, S. (2016). Pengaruh Reputasi Underwriter, Return on Asset, Return on Equity, Debt To Equity Ratio, Dan Ukuran Perusahaan Terhadap Tingkat Underpricing Pada Penawaran Umum Perdana Di Bei Periode 2011-2013.

Akbar, D. A., \& Africano, F. (2020). Pengaruh Reputasi Underwriter Dan Umur Perusahaan, Terhadap Underpricing Saham Pada Saat Initial Public Offering. Jurnal Al-Qardh, 4(2), 129-141. https://doi.org/10.23971/jaq.v4i2.1660

Asrini, A. (2017). MODEL UNDERPRICING PADA PENAWARAN UMUM PERDANA (IPO) PADA PERUSAHAAN GO PUBLIC. Develop, l(2).

D. Alviani, \& Lasmana, A. (2015). Analisis Rasio Keuangan ROA, ROE, Price Earning Ratio Terhadap Underpricing Saham Perdana. Studi Kasus: Perusahaan yang Melakukan IPO di BEI Periode 2008-2011. Jurnal Akunida, 1(1), 1-8.

Dewi, K. M. S., Tripalupi, L. E., \& Haris, I. A. (2018). Pengaruh Return on Equity (Roe) Dan Earning Per Share (Eps) Terhadap Underpricing Pada Saham Perdana Di Bursa Efek Indonesia Tahun 2016. Jurnal Pendidikan Ekonomi Undiksha, 10(1), 200. https://doi.org/10.23887/jjpe.v10i1.20115

DJASHAN, I. A. (2018). Analisis Faktor-Faktor Terhadap Underpricing Saham Perdana. Jurnal Bisnis Dan Akuntansi, 19(2), 251-258. https://doi.org/10.34208/jba.v19i2.277

Gunawan, M., \& Jodin, V. (2017). Faktor-Faktor Yang Mempengaruhi Tingkat Underpricing Saham Pada Perusahaan Yang Melakukan Initial Public Offering Yang Terdaftar Di Bursa Efek Indonesia. Jurnal Ekonomi, 20(2), 174-192. https://doi.org/10.24912/je.v20i2.155

Hadi, S. (2019). Faktor-faktor yang mempengaruhi Underpricing Saham Perdana pada Perusahaan yang melakukan Initial Public Offering. Jurnal Akuntansi \& Perpajakan Jayakarta, 1(1), 64-75.

Haska, D., Rokhmawati, A., \& Sjahruddin, S. (2016). Pengaruh Risiko Investasi, Return on Equity (Roe) Dan Proceeds Terhadap Underpricing Dengan Reputasi Underwriter Sebagai Variabel Moderasi Pada Perusahaan Non-Keuangan Yang Ipo Di Bei Periode 2010-2014. Jurnal Online Mahasiswa Fakultas Ekonomi Universitas Riau, 4(1), 1-14.

Lestari, F. A., \& Sulasmiyati, S. (2017). ( Studi Pada Perusahaan Yang Melaksanakan IPO Pada Bursa Efek Indonesia Tahun. Jurnal Administrasi Bisnis, 46(2).

Mayasari, T., . Y., \& Yulianto, A. (2018). Pengaruh Return on Equity, Net Profit Margin dan Ukuran Perusahaan Terhadap underpricing. Jurnal Kajian Akuntansi, 2(1), 41. https://doi.org/10.33603/jka.v2i1.1271

Muharam, H., \& Firmanah, D. U. (2015). Analisis Pengaruh Informasi Non Keuangan, Informasi Keuangan, dan Ownership Terhadap Underpricing pada Perusahaan Non Keuangan yang Melakukan Initial Public Offering ( IPO ) di BEI Periode 20082014. Diponegoro Journal Of Manajement, 4(4), 1-12.

Nadia, R., \& Daud, R. M. (2017). Pengaruh Informasi Keuangan dan Non Keuangan terhadap Initial Return pada Perusahaan yang Melakukan Penawaran Umum Saham Perdana di Bursa Efek Indonesia Periode 2014-2016. Jurnal Ilmiah Mahasiswa Ekonomi Akuntansi (JIMEKA), 2(3), 1.

Permatasari, R., \& Kusumah, R. W. R. (2017). Pengaruh Return On Asset, Price Earning Ratio, Ukuran Perusahaan, Prsentase Penawaran, Saham, dan Reputasi Underwriter Terhadap Tingkat Underpricing. ( Studi Pada Perusahaan yang Melakukan Initial Public Offering di Bursa Efek Indonesia Periode 2008-2015 . Proceedings 
Profesionalisme Akuntan Menuju Sustainable Business Practice, SNAB UNIVERSITAS WIDYATAMA, 261-277.

Purwanto, S. W. A., Salman, F. I., \& Budi, W. (2015). Pengaruh Struktur Corporate Governance Terhadap Initial Public Offering (IPO) Underpricing Di Indonesia. Jurnal Ekonomi Bisnis Dan Kewirausahaan, 4(1), 86-114.

Rabiqy, Y. dan Y. (2017). 3 The Factors Underpricing Level in The Companies Conducting Initial Public Offering At Indonesia Stock Exchange. AFEBI Management and Business Review (AMBR), 8-20.

Saifudin, S., \& Rahmawati, D. (2017). Pengaruh Informasi Akuntansi Dan Non Akuntansi Terhadap Underpricing Ketika Initial Public Offering Di Bursa Efek Indonesia. Jurnal Penelitan Ekonomi Dan Bisnis, 1(1), 33-46. https://doi.org/10.33633/jpeb.v1i1.1478

Saputra, A., \& Suaryana, I. (2016). Pengaruh Umur Perusahaan, Ukuran Perusahaan, Return on Assets Dan Financial Leverage Pada Underpricing Penawaran Umum Perdana. E-Jurnal Akuntansi, 15(2), 1201-1227.

Setyowati, T. K., \& Suciningtyas, S. A. (2018). Analisis Tingkat Underpricing Saham Pada Perusahaan yang Melakukan Penawaran Saham Perdana (IPO) di BEI Periode 2012-2016. Jurnal Universitas Islam Sultan Agung Semarang, 19, 89-98.

Subur Harahap. (2017). Studi Tentang Kinerja Keuangan Dan Tingkat Pengembalian Saham Dalam Fenomena Underpricing Initial Public Offering (IPO) di Bursa Efek Indonesia. 20(1), 17-34.

Utami, E., Illiyyin, N., \& Gumanti, T. (2019). Intellectual Capital Disclosure and the Underpricing of Indonesian Initial Public Offerings. 19(1), 94-103.

Valantina, M., Sugara, K., Manajemen, J., \& Multi, S. (2017). Pengaruh Return on Asset ( Roa ), Financial Leverage, Umur Perusahaan Dan Reputasi Underwriter Terhadap Underpricing Pada Saat Initial Public Offering ( Ipo ) Di Bursa Efek Indonesia Periode 2013-2017. 1-13.

Widhiastina, P., \& Prihatni, R. (2016). Pengaruh Return on Asset, Financial Leverage, Dan Ukuran Perusahaan Terhadapunderpricing Pada Perusahaan Yang Melakukan Initial Public Offering (Ipo) Di Bursaefek Indonesia. Jurnal Wahana Akuntansi, 11(2), 35. https://doi.org/10.21009/10.21.009/wahana.011/2.3

Wiyani, N. (2016). Underpricing pada Initial Public Offering (Studi Empiris pada Perusahaan Non Keuangan yang Go Public di Bursa Efek Indonesia Tahun 2011 2014). Jurnal Online Insan Akuntan, 1(2), 341-358.

Yuliani, Y., Wahyuni, D., \& Bakar, S. W. (2019). The Influence Of Financial And NonFinancial Information To Underpricing Of Stock Prices In Companies That Conduct Initial Public Offering. Ekspektra : Jurnal Bisnis Dan Manajemen, 3(1), 39. https://doi.org/10.25139/ekt.v3i1.1442 